\title{
Cooperation as an integral part of the social and solidarity economy (SSE)
}

\author{
Vladimir Egorov, and Andrey Inshakov* \\ Plekhanov Russian University of Economics, 117997 Moscow, Russian Federation
}

\begin{abstract}
A theoretical analysis of the works of domestic and foreign authors on the problem of determining the place and role of the social (solidarity) economy (SSE) organization in the modern world economic space is carried out. The essential features of social (solidary enterprises) are revealed. The SWOT analysis allowed us to determine the strengths and weaknesses of the SSE organizations. The differences between nonprofit and market economy are shown. The essential features of cooperation as the main socio-economic institution of the SSE are considered. Mechanisms for reducing global poverty by cooperatives have been identified. The factors constraining the progressive development of cooperative enterprises in Russia are identified.
\end{abstract}

\section{Introduction}

Social justice in modern reality acquires, as in the days of the French enlightenment, a system-forming value, an imperative that determines not only the further development, but also the existence of a planetary civilization. Human rights, openness and participation in political decision-making are becoming a prerequisite for sustainable development, which is a fundamental principle of the international community, as expressed by the United Nations.

Traditional models of economic growth, which have been relatively successfully implemented over the past two decades, need to be significantly corrected. First of all, in terms of finding effective mechanisms to overcome global challenges, including the elimination of poverty and misery, which can, against the background of increasing inequality, lead to a violation of socio-political stability and chaotic societies.

The social and solidarity economy (SSE) is an important means of ensuring that the principles of social justice are respected and that the welfare of the neediest segments of the population is taken into account in the development process.

The works of V. A. Sautkina [1], S. Borzaghi [2], E. Bryndin [3], J. Deforni [4,5,6], A. Dash [7], E. Cavanaugh [8], J. Laveli [9], S. Stereo [10], B. Fontenot [11], and others are devoted to the problems of social and solidarity economy, as well as issues of its provision.

Although the term "third sector" is mainly used in english-language literature to describe the private non-profit sector, which is mainly composed of associations and

\footnotetext{
* Corresponding author: aero789@mail.ru
} 
foundations, at the same time the term is used in continental Europe and other parts of the world as a synonym for social and solidarity economy.

The American researcher Levitt [12] was one of the first to use the expression "Third sector" in 1973, identifying it with the non-profit sector. In Europe, the same term was used several years later to describe the sector located between the state and capitalist, which is much closer to the concept of social economy. [13, 14]

One of the essential characteristics of a solidary economy is the integration of a cooperative form of socio-economic organization into its body.

The first enterprises of this type appeared in England in the XIX century. Today they exist all over the world in various fields - agriculture, credit, insurance, trade, housing and utilities, etc. All of them operate on the basis of the prohibition of income redistribution, i.e. they are designed only to meet the needs of their members, who are their owners. The International Cooperative Alliance currently unites about 750 million members of cooperative enterprises on five continents. [15]

The analysis of foreign literature has allowed to reveal features of the social (solidarity businesses). [16] these, according to researchers, include:

1) having the status of private enterprises;

2) have independent decision-making, which means that they have the ability to choose and dismiss their governing bodies, as well as to control and organize their activities;

3) recognizing the freedom of membership procedure;

4) distributing profits or surpluses among user members, if any, not in proportion to the capital or shares contributed by members, but in proportion to their activities or transactions with the organization;

5) conducting independent economic activities aimed at meeting the needs of individuals, households or families. For this reason, organizations of the social economy are called organizations of people, not of capital;

6) applying the principle of "one person - one vote" in decision-making, regardless of the capital or shares contributed by members;

7) organizations that are guided by democratic principles. The democratic criterion is considered a necessary condition for a company to be considered part of the social economy, since the social utility of these companies is usually based not on their economic activities, but on their goals and on the democratic values that guide their activities.

Table 1. Similarities and differences between non-profit and market economies [17]

\begin{tabular}{|l|l|}
\hline \multicolumn{1}{|c|}{ Non-profit economy } & Market (capitalist) economy \\
\hline \multicolumn{2}{|c|}{ The main motive for production } \\
\hline \multicolumn{2}{|c|}{ Economic order } \\
\hline \multicolumn{2}{|c|}{ Gatisfaction of needs } \\
\hline $\begin{array}{l}\text { The main economic issues are resolved by system } \\
\text { integrity and are determined by the interests of } \\
\text { shareholders }\end{array}$ & $\begin{array}{l}\text { The price and salary are determined } \\
\text { based on market expediency }\end{array}$ \\
\hline \multicolumn{2}{|c|}{ Strength } \\
\hline $\begin{array}{l}\text { - Moral and ethical basis of economic relations. } \\
\text { - Organizes effective satisfaction of society's needs by } \\
\text { reducing costs. }\end{array}$ & $\begin{array}{l}\text { - Encourages high enterprise and } \\
\text { efficiency. } \\
\text { - Unites people on the principle of common goals. } \\
\text { - Develops comprehensive communication and } \\
\text { information support for its activities }\end{array}$ \\
\hline
\end{tabular}


Continuation of Table 1. Similarities and differences between non-profit and market economies

\section{The economy development trends}

- Ensures sustainable and safe development of society in accordance with moral principles.

- The potential for broad, large-scale implementation of digital products in the industry not only in the production process, but also in decision-making mechanisms at all levels.

- The potential of algorithmization of most economic processes-improving the overall quality of management.
- Increases inequality in society.

- Does not provide social stability.

- It is not aimed at providing non-profit benefits necessary for society. - Indifferent to the damage that business can cause to people and nature.

Currently, organizations representing the social economy in Europe can be divided into 4 groups: 1) Cooperative family (EURTOCOOP, CECODHAS, CECOP, COGECA, GEBC, Cooperatives Europe); 2) Community of mutual aid societies (AIM, AMICE); 3) Community of social associations (CEDAG, EFC); 4) Platforms for social enterprises (CEFEC). [16]

The purpose of this article is to explain the place and role of cooperation in the modern social process.

\section{Materials and Methods}

The use of the method of historicism allowed us to evaluate the social and solidarity economy (SSE) from the point of view of the embeddedness of this phenomenon in the cultural process. Through SWOT analysis, it was possible to identify the strengths and weaknesses of SSE enterprises, including cooperatives, in comparison with private capitalist forms of economy. The phenomenological approach made it possible to determine the essential qualities of the main socio-economic institution of SSE-cooperation. The statistical method was used to present the dynamics of social processes, an important factor of which is cooperative solidarity.

\section{Results}

The accumulated experience of joint actions, analysis and interpretation of their consequences shows that the presence or absence of a request for solidarity in society is most clearly manifested during a crisis, when under the pressure of a variety of challenges that not only worsen the situation of citizens, but constitute a real threat to their existence, there is a need for solidarity behavior. In these circumstances, more and more people are realizing the need to sacrifice their interests and join the group of people who see actions based on the principles of solidarity as the only way to solve their pressing problems. Each specific time gives rise to its own forms and ways to unite, but it is always the ability to act in solidarity that helps peoples not only survive, but also reach a new stage of their development. In the modern era of transition to the information society, cooperation is acquiring a new and growing social role.

The social character of cooperatives, namely their ability to go beyond the boundaries of group solidarity, is determined by the following institutional features:

1. the Cooperative principle of "voluntary and open membership", which implies that anyone who meets the formal criteria of membership can potentially be a cooperator, "both today and in the future". 
2. the Cooperative principle of participation of members in the formation and disposal of cooperative property, in the creation of common reserve funds that remain indivisible even after the termination of the activities of cooperative associations.

3. the Cooperative principle of "caring for the public as a whole", which manifests itself in the solidarity behavior of members, the motives of which coincide with social strategies.

4. the Inherent property of cooperatives to cooperate with other cooperatives and create a "cooperation among cooperatives" (cooperative industries and the cooperative sector of the economy).

The most consistent social character is shown in the association of consumers who are initially by their nature public organizations. The dialectical contradiction between corporate interests and the interests of society is overcome in this form of cooperative unions as a result of minimizing collective ownership, which limits the desire for social consolidation. Another essential characteristic of consumer societies that determines their social orientation is the absence of restrictions on the number of shareholders due to institutional quality. Cooperative practice shows that the mass movement of consumers not only does not prevent the realization of the advantages of this form of socio-economic organization, but on the contrary significantly expands its capabilities.

The importance of consumer unions as a mechanism for eliminating social imbalances directly follows from another essential quality of their nature. Consumer society was born and developed not as a form of organization that provides market preferences of the owners, and companies need to cheaper products and services for personal consumption.

It is the social nature of cooperation that makes this form of socio-economic organization the most complementary mechanism in solving acute social problems, including overcoming poverty.

The issue of increasing poverty is particularly relevant in the current global economic situation. According to the World Bank, the pandemic that began in 2019 is pushing more and more urban residents around the world into extreme poverty [18].

The number of people living in extreme poverty is expected to grow to 150 million by 2021. Eight out of ten new poor people will live in middle-income countries. [19]

The wealth of Russian households per adult fell by $10.7 \%$ in the first half of 2020 . This is more than in Colombia, Great Britain and Turkey (minus 6-7\%), Chile and Ukraine (minus 8-9\%). According to Credit Suisse, Mexico (minus 14.2\%), South Africa (minus 21.8\%) and Brazil (minus 24.4\%) showed the maximum decline in the welfare of citizens. [20]

According to VTCIOM surveys, $12 \%$ of Russians consider the current economic situation in the country to be good, while $49 \%$ rate it as average. $60 \%$ of Russians consider their family's financial situation to be mostly average [21].

According to Rosstat, the real disposable income of the Russian population in the third quarter of 2020 decreased by almost 5\%, after a record drop of $8.4 \%$ in the second. [22] as a result of the fall in the national currency in Russia, the minimum subsistence level fell from $\$ 156.17$ in 2019 to $\$ 149.49$ in 2020. [22]

Russians polled by VTCIOM believe that the main factors provoking the growth of poverty in Russia include: unfair distribution of the Russian budget, massive cuts in enterprises, and social inequality. [23]

Thus, the development of social (solidarity) cooperative enterprises as a mechanism for overcoming poverty is one of the most pressing social problems. In 2016 SEFORIS Agency presented the industry structure of Russian socially oriented enterprises: education $-10 \%$, business-related services- $41 \%$, social security system- $26 \%$, education and research- $15 \%$, environment-22\%. [24]

The share of cooperation among social enterprises in different countries has a large variation in size. 
Among social enterprises, the cooperative model is most common in Hungary $(40 \%)$, Romania (18\%), and Sweden (7\%). [24]

Despite the demand, consumer cooperation is significantly less represented in the Russian socially-oriented segment of the public economy. One of the main reasons for this state of affairs remains its structural appearance, inherited from the Soviet administrativeplanned, centralized system, part of which was the consumer cooperative, united in the Centrosoyuz.

The information and communication revolution, the results of which are actively spreading, including on the territory of Russia, opens up new opportunities for the development of the cooperative movement. The expansion of network connections and relationships within the public communication space multiplies the social effect of cooperative solidarity many times over.

With the introduction of innovative technologies used by consumer unions, their role in the development of rural areas, which are the focus of poverty and misery, is significantly increasing. According to research conducted in Indonesia and Kenya, the preservation of self-governing and self-sufficient rural locations depends on improving their infrastructure and the comfort of rural residents ' living space provided by consumer associations. [25]

An analysis of global experience has revealed how cooperatives contribute to poverty reduction:

1. Contribute to sustainable economic growth: the combined turnover of the world's 300 largest cooperatives is $\$ 1.1$ trillion. Cooperatives employ more than 100 million people (more than multinational corporations), and they contribute to increasing agricultural productivity, increasing access to financial services, and essential utilities such as electricity and water. [26]

2. Cooperatives can help organize markets for the poor by creating economies of scale, increasing access to information, and improving communication capacity. The result of cooperative activities remains on the ground, and is not transmitted outside the territories.

3. Cooperatives increase the productivity and income of small farmers by helping them collectively negotiate better prices for seeds, fertilizers, transport and storage. They help farmers expand access to markets and master most of the production chains by organizing processing activities. Cooperatives are often the main channel through which small farmers gain access to fair trade, which guarantees a favorable price and additional funds for investment.

4. Increase access of the poor to financial services, including credit and insurance. These services can help start and expand businesses; take risks that can lead to higher profitability; reduce vulnerability by allowing the poor to accumulate savings, build up assets, and smooth out consumption imbalances. Cooperatives are one of the largest providers of microfinance services for the poor, reaching 78 million people worldwide who live on less than $\$ 2$ a day.

5. Provide a wide range of services in healthcare, housing, utilities, water and electricity. Cooperatives have been successful in expanding access to clean water, electricity, and utilities. In Bangladesh and the United States, rural electric cooperatives are set up to meet the needs of their own communities without the ability to attract external investors. In Bangladesh, cooperative enterprises provide public services to 28 million people, with initial support from the Ministry of Foreign Affairs and USAID.

6. Provide opportunities for self-government and empowerment of the poor: they promote culture, citizenship, and enable their members to have a voice and participate in the democratic process, thereby influencing development beyond economic benefits.

7. Contribute to the prevention of social tension. Where cooperatives bring together people from different religious, ethnic, and political groups, they produce trust and solidarity that lead to greater social stability. Cooperatives have been found to help restore 
relations after conflicts by strengthening positive relations between conflicting ethnic groups in Bosnia, East Timor, Lebanon, Macedonia, Mozambique, Nepal and Rwanda.

\section{Discussion}

One of the obstacles to the development of the Russian cooperative movement is the inadequacy of its legal support. In Russia, there is no framework law that defines the specific differences between cooperatives and the nature of different forms of cooperative organization. In terms of legal support for cooperation in Russia, it is necessary: first, a clear legal regulation of the features of cooperative identity. For example, associations of physical and legal members cannot be defined as cooperative, just like private capitalist and cooperative enterprises integrated in holdings.

Second, the legal assessment of different types of cooperative associations: producers and consumers. It does not adequately reflect the nature of different types of cooperation, the existing legal status of "consumer agricultural cooperation", which unites institutions of various substational nature.

Third, the further development of the cooperative movement, including in innovative activities, requires their special legal support. For example, there is clearly a need for legislative consolidation of cooperative cooperation in the information sphere and the field of artificial intelligence.

Another unresolved issue that complicates the growth of cooperation is the lack of a development-oriented state policy. With regard to commodity producers, the state policy should focus on measures that increase their financial viability and the marketability of their farms, producing trends towards concentration, and not attempts to artificially increase (by means of propaganda and grant support) the number of cooperative enterprises.

Preferential fiscal and credit policies should be applied to consumer cooperatives that maintain their social quality and focus on creating comfortable conditions for consumption, including low-income citizens. It is quite justified to provide such associations with preferential leases of state property, including premises.

The state should pay close attention to any attempts to hide illegal activities under the "cooperative sign" and the facts of receiving preferential grant support.

The lack of responsibility for violations of cooperative legislation and principles of cooperation leads to the emergence of a significant number of pseudo-cooperatives, illegal actions on the part of the management of cooperatives, violation of the legal rights and interests of cooperatives, which ultimately leads to discrediting the cooperative movement. [27]

Adequate development of cooperation in the new civilizational conditions dictates the need to actively attract highly qualified young people to its ranks.

In France, the national Confederation of workers ' cooperatives CG Scop reported that in 2015, young managers ( $<35$ years old) they accounted for $15.5 \%$ of all managers in workers ' and social cooperatives, compared to $11.3 \%$ in ordinary enterprises. [28] According to the Spanish Confederation of workers 'cooperatives COCETA, youth participation in cooperatives in Spain shows very promising trends, given that in some provinces $80 \%$ of the members of newly created workers' cooperatives are under 35 years of age (figure presented in 2015). [29] The potential of the cooperative sector to address the problem of youth employment in Europe was recognized by the European Commission, which in 2016 called for proposals specifically aimed at promoting best practices to combat youth unemployment by helping young people to establish and work in cooperatives through innovative schemes and training modules.

The destruction of the system of training cooperative personnel in Russia in the 1990s and the re-profiling of cooperative universities, in fact, implies the creation of a new 
modern educational complex, which, of course, is impossible to implement without state aid.

International experience shows that an effective means of developing the consumer cooperative movement is the promotion and dissemination of best practices. The need to deploy such work in Russia is obvious. Having a huge historical experience of cooperative construction in Russia, the idea of cooperation in the public consciousness is distorted by its mutation in the administrative-planned, centralized Soviet system, and perestroika "chaos" and disorder. Almost half of Russians, according to VTCIOM, represent cooperation in the form of Soviet "Selpo", collective farms or criminal structures of the end of the last century. [30]

Another structural characteristic of modern Russian society lies in the task of restoring a positive image of cooperation and its constructive social functions, namely, the loss of trust in the organization that is necessary for cooperation.

An American research company has published an annual rating of trust of people from different countries of the world to public institutions and institutions of power (33 thousand people participated in 28 countries). [31]

Russia ranked last in terms of overall confidence and is at the bottom of the rating in most sections of the report.

The index of trust of Russians to public institutions is 29 out of 100 . Russia was also among the leaders in terms of falling confidence over the year: at the beginning of 2018, the country's confidence index was 36 points, being in last place in terms of confidence in nonprofit organizations ( $23 \%$ of respondents trust them, compared to $74 \%$ in China, $59 \%$ in Canada and $47 \%$ in the UK). [32]

\section{Conclusion}

1. the role and significance of socio-economic forms of organization based on the democratic principles of participation, openness and justice, the core of which is cooperation, are being updated in the context of declining effectiveness of traditional public development institutions.

2. the social orientation of cooperation is directly determined by its nature and essential qualities. However, consumer societies demonstrate their social content in the most consistent way. In the context of growing inequality, the ability of consumer cooperatives to address social disparities and tensions is of particular importance.

3. Consumer cooperation in the emerging information society acquires a qualitatively new (high) level of animated social effect.

4. an important role in the development of the cooperative movement belongs to: legislative support for cooperative identity, socially oriented state policy, promotion of the world experience of cooperative solidarity and organization of cooperative education.

\section{Acknowledgments}

The Work was carried out within the framework of the RFBR grant 18-010-00437 "Cooperation as an instrument for development rural areas and economic self-organization of population", contract № 18-010-00437\20 dated March 31, 2020.

\section{References}

1. V. A. Sautkina. Public request for solidarity: historical retrospective and modern reality, South-Russian journal of social Sciences, 2, 70 (2019) 
2. C. Borzaga, J. Defourny, The Emergence of Social Enterprise, London and New York, Routledge, 350 (2001)

3. E.G. Bryndin, International economic solidarity, Byuleten Mizhnarodnogo Nobelivskogo ekonomichnogo forumu, 1 (5), 30 (2012)

4. J. Defourny, Concepts and realities of social enterprise: a European perspective. Handbook of research on social entrepreneurship, 57(2010)

5. J. Defourny, P. Develtere , B. Fonteneau \& M. Nyssens (Eds.), The worldwide making of the social economy, innovations and changes. Leuven, Belgium: Acco. (2009)

6. J. Defourny, L. Hulgard, V. Pestoff, Social Enterprise, Social Entrepreneurship, Social Economy, Solidarity Economy: An EMES Reader on the «SE Field», EMES European Research Network (2010)

7. A. Dash, Towards an epistemological foundation for social and solidarity economy, Potential limits of social and solidarity economy, Geneva, 6, (2013)

8. E. Kawano, Social Solidarity Economy: Toward Convergence across Continental Divides, https://www.unrisd.org/

9. J.L. Laville, Socialand solidarity economy: A theoretical and plural framework, Potential limits of social and solidarity economy, Geneva, 15, (2013)

10. S. Stjernø, Solidarity in Europe: The history of an idea, Cambridge university press, 408 (2005)

11. B. Fonteno, Social and Economic Solidarity: General concepts, (2010)

12. T. Levitt, The Third Sector: New Tactics for A Responsive Society. New York: Amacom Press (1973).

13. T. Jeantet, Economic sociale. La solidarité au défi de l'efficacité, Paris: La documentation française (2006)

14. J. Defourny, J. L. Monzon Campos, Econo-mie sociale (entre économie capitaliste et écono-mie publique), Third sector (cooperative, mutualand nonprofit organizations), Ciriec-De Boeck Université, Bruxelles (1992)

15. International cooperative alliance, https://www.ica.coop/en

16. J.L.Monzón Campos, R. Ch. Āvila, The social economy in the European Union (2012)

17. Socio-economic project of the non-profit economy of the National Consumer Society, https://po-npo.ru/

18. La pandémie précipite entre 88 et 115 millions de personnes dans l'extréme pauvreté, https://www.courrierinternational.com/

19. Credit Suisse praised the impoverishment of Russians during the pandemic, https://www.rbc.ru/

20. The Situation in the country and in the economy: monitoring sentiment, VTCIOM, https://wsiom.ru/

21. Real disposable incomes of Russians continued to fall, RBC, https://www.rbc.ru/

22. Rosstat, https://rosstat.gov.ru/

23. VTCIOM, http://wciom.ru/

24. Report on the country Russia. The first analysis of Russian social enterprises prepared by the research consortium, SEFORIS (2016)

25. J. Hamory, M. Kleemans, Y. Li Nicholas, E. Miguel, Reevaluating Agricultural Productivity Gaps with Longitudinal Microdata (2017)

26. Helpdesk Research Report: Cooperatives and development (2011), https://gsdrc.org/ 
27. VIII all-Russian Congress of agricultural cooperatives, draft Resolution of the Congress, https://fsspk.ru/

28. Les Scop, La CG Scop soutient les jeunes coopérateurs (2015), www.les-scop.coop/

29. Observatorio Español de la Economía Social (2016), www.observatorioeconomiasocial.es/

30. The Desire to become farmers among Russians is cooling. Collective farms and VTCIOM are again recognized as the most effective form of land management, https://wciom.ru/

31. Cooperatives as a factor of increasing public confidence, https://pravo-wmeste.ru/

32. Edelman Trust Barometer Global Report (2019), https://www.edelman.com/ 